Policy analysis

\title{
Contrasting long-term population trends of beach-nesting shorebirds under shared environmental pressures
}

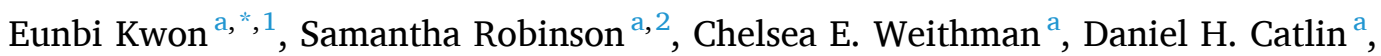 \\ Sarah M. Karpanty ${ }^{a}$, Jon Altman ${ }^{b}$, Theodore R. Simons ${ }^{c}$, James D. Fraser ${ }^{a}$ \\ ${ }^{a}$ Department of Fish and Wildlife Conservation, Virginia Tech, Blacksburg, VA 24060, USA \\ ${ }^{\mathrm{b}}$ National Park Service, Cape Lookout National Seashore, Harkers Island, NC 28531, USA \\ ${ }^{\mathrm{c}}$ U.S. Geological Survey, North Carolina Coop. Fish and Wildlife Research Unit, Dept. of Zoology, North Carolina State Univ., Raleigh, NC 27695, USA
}

\section{A R T I C L E I N F O}

\section{Keywords:}

American oystercatcher

Barrier island

Conservation

Human disturbance

National Park Service

Piping plover

\begin{abstract}
A B S T R A C T
Identifying the drivers of long-term population change is a key goal of ecological studies. It is complicated by extrinsic and intrinsic factors that may covary with time and/or operate on a time lag. For migratory shorebirds that breed on the barrier islands of eastern North America, populations may be limited by the anthropogenic, climatic, biological environments they encounter throughout the annual cycle. Using three-decades (1989-2017) of breeding monitoring data collected by the National Park Service at two national seashores in North Carolina (Hatteras and Lookout), we examined the potential drivers of nesting piping plover (Charadrius melodus) and American oystercatcher (Haematopus palliates) populations. Hatteras had five times more annual visitors than Lookout, and our modelling revealed a strong negative relationship between the population size of breeding plovers and human activity and a positive relationship with protection efforts aimed at reducing disturbance. Breeding and wintering climatic conditions, population productivity, and nesting habitat availability showed only weak effects. Thus, a decade-long decline in plover numbers at both seashores starting in the mid-90s reversed as the parks' visitor counts decreased and stricter protections from potential disturbance were implemented. However, the two sympatric populations of oystercatchers showed the opposite population trends from each other at the neighboring seashores, increasing only on Lookout after a hurricane improved habitat and subsequently the reproductive output. Our study suggests a strong relationship between the anthropogenic environment and the population trend of a threatened species and, simultaneously, the important role of stochastic events in shaping populations of long-lived shorebird species.
\end{abstract}

\section{Introduction}

Long-term population changes are driven by both extrinsic and intrinsic factors (Turchin, 1999). Extrinsic factors impose external forcing on population numbers but are not affected by the population (e. g., weather and climate: Hsieh and Ohman, 2006). Intrinsic factors provide dynamic feedback that affects population numbers, often with a time lag (e.g., density dependence: Turchin, 1999). Concerning breeding birds, studies report the effects of extrinsic factors (Plard et al., 2019) as well as intrinsic population dynamics, such as density-dependent recruitment, on population trends (Sæther et al., 2002; Gunnarsson et al., 2005; Catlin et al., 2019; Robinson et al., 2019) or lack thereof
(Wann et al., 2014).

Unlike non-migratory species, the population size of a migratory species at one location can be driven by conditions at other locations (reviewed by Newton, 2004; Harrison et al., 2011). For example, climate can affect bird populations in numerous ways (Mustin et al., 2007); some effects occur on wintering grounds (Davidson, 1981; Newton, 2007; Wann et al., 2014), some during migration (Newton, 2006, 2007), and some on breeding grounds (Barbraud and Weimerskirch, 2001; González-Braojos et al., 2017). Extrinsic factors can be as short-lived and localized as a single weather event (Newton, 2006, 2007) or can be a long-term trend that acts at the hemispheric level, such as the North Atlantic Oscillation (NAO) index (Møller, 2002; van de Pol et al., 2010;

\footnotetext{
* Corresponding author.

E-mail address: eunbi.kwon@gmail.com (E. Kwon).

1 Current affiliation: Department of Behavioural Ecology and Evolutionary Genetics, Max Planck Institute for Ornithology, Seewiesen, Germany.

2 Current affiliation: Delaware Division of Fish \& Wildlife, Smyrna, DE 19977, USA.
} 
Sandvik et al., 2012). Populations also may be limited by inter-specific linkages such as predator-prey interactions (Dowding and Murphy, 2001) or direct human-wildlife associations, especially for game species (Packer et al., 2011). However, the anthropogenic impacts on population trends often are indirect through resource limitation, making it difficult to discern a causal link (Stillman et al., 2001).

For shorebirds that nest on temperate beaches, the negative ecological consequences of human presence and potential disturbance have been well documented, such as through behavioral changes (Verhulst et al., 2001; Baudains and Lloyd, 2007; Koch and Paton, 2014), physiological costs (Weston and Elgar, 2005), reduced reproductive success (Dowling and Weston, 1999; Baudains and Lloyd, 2007; DeRoseWilson et al., 2018), or improved reproductive output when protected against human disturbance (Weston et al., 2012). However, relatively few studies have shown the impact of human disturbance on long-term population changes (West et al., 2002; Lafferty et al., 2006) despite the importance of understanding the anthropogenic impacts for setting conservation priorities (Gill et al., 2001).

Long-term monitoring and time-series data are necessary to distinguish a directional trend from annual population fluctuations, and the relative roles of both intrinsic and extrinsic factors, especially where there are time lags and complex relationships among potential population drivers (Yalden and Pearce-Higgins, 1997; Grenfell et al., 1998; Bjørnstad and Grenfell, 2001). Given the cost of collecting long-term datasets, an alternative is to use data collected by government agencies charged with monitoring imperiled species (e.g., U.S. Fish and Wildlife Service, National Park Service).

We used long-term population monitoring data on beach-nesting shorebirds collected by the National Park Service at two national seashores in North Carolina (USA) over three decades to understand the relative and/or interacting influences of intrinsic and extrinsic population drivers of two imperiled nesting migratory shorebirds. Multiple drivers can shape a population's trajectory (Yalden and Pearce-Higgins, 1997), and a single extrinsic factor can have contrasting population effects in sympatric species if their life-history traits differ (Jenouvrier et al., 2005; Forcada et al., 2006). We compared the population trajectory of piping plovers (Charadrius melodus; 'plovers') and American oystercatchers (Haematopus palliates; 'oystercatchers') that were monitored at Cape Hatteras National Seashore and Cape Lookout National Seashore. Atlantic Coast plovers are listed as federally threatened under the U.S. Endangered Species Act, and oystercatchers are state-listed as a species of special concern in North Carolina. The two species differ in their life histories and feeding habitat but share similar nesting habitat (see Methods-Study species). Both species at both seashores were protected from potential human disturbance on the beach, however, the extent and intensity of protection varied throughout the years and by seashore. Both parks have similar geomorphologies and natural processes, but Cape Hatteras is bisected by a highway and attracts many more visitors annually than Cape Lookout where the beaches are accessible only by boat.

The objective of this study was to compare annual variation of intrinsic and extrinsic factors with population sizes of breeding shorebirds, using a 29-year monitoring dataset. Although birds could freely move between the two seashores, only three out of 108 banded plovers and none of 274 banded oystercatchers were seen nesting in both seashores (data only from confirmed breeders; this study, unpublished data). Based on data available for plovers, these two seemingly independent breeding populations at two seashores, however, showed the same population fluctuations across years which were not explained by the regional trend in population sizes (see Fig. S1). Therefore, we could assume that a local process at the breeding ground, or at the wintering ground if the two populations share similar wintering distributions, was responsible for population trends at the two seashores. We a priori hypothesized that the same local process can shape the population trends of the oystercatchers that are sympatric with plovers. Based on the relatively high rate of natal philopatry known for both species
(McGowan et al., 2005b; Weithman et al., 2019), we suspected a positive correlation between the population productivity and future breeding population size. However, the extent to which population productivity contributes to population trends is expected to differ between the two species, as oystercatchers live longer and mature later than plovers (oystercatcher vs. plover survival rates in North Carolina: adults $92 \%$ vs. $69 \%$, juveniles $48 \%$ vs. $8 \%$; Simons and Schulte, 2009; Simons and Stocking, 2011; Weithman et al., 2019). Therefore, we predicted the effect of population productivity on future population size to be stronger with plovers than oystercatchers (Table 1-(3)). Given the extent of human-wildlife conflict and enforced conservation actions at the seashores (Mansfield et al., 2011; Merritt and Shafer, 2012; Dundas et al., 2016), we also predicted that the annual number of park visitors and the presence of enhanced protection measures would affect population trajectory, especially at Cape Hatteras National Seashore, where there are 5 times more summer users than at Cape Lookout National Seashore (Table 1-(4 \& 5)). Lastly, we included annual changes in habitat availability into our model as it is considered an important population driver for both species (Table 1-(6); Working Group et al., 2012; Robinson et al., 2019).

\section{Methods}

\subsection{Study species}

Both species are common breeders on the Outer Banks of North Carolina and have been monitored and protected by the NPS since around 1989. Both breed from April to August, building nest scrapes near sandy dunes and on open or sparsely vegetated beaches, although oystercatchers occasionally nest on shell beds or rooftops (Lauro and Burger, 1989; Douglass et al., 2001; Elliott-Smith and Haig, 2004). Both species show strong site fidelity ( 0.94 for adult plovers (Weithman et al., 2019) and 0.89 for adult oystercatchers (Simons and Schulte, 2009)), incubate their clutch for 26-27 days, and provide bi-parental care to precocial chicks (McGowan et al., 2005a, 2005b; Kwon et al., 2018). However, the two species differ in their feeding habits; in that plovers feed on small invertebrates on beaches and bayside intertidal flats (Elias et al., 2000; Cohen et al., 2009), whereas oystercatchers mainly feed on large bivalves on mud flats and in the ocean intertidal zone (Nol, 1989). Moreover, plovers are smaller-bodied (ca. $50 \mathrm{~g}$ vs. $>500 \mathrm{~g}$ ), presumably with a shorter lifespan, and plover chicks take ca. 10 fewer days to fledge than oystercatcher chicks do (25 vs. 35 days; Elliott-Smith and Haig, 2004; Working Group et al., 2012). Since plover nests were protected with a predator exclosure (USFWS, 1996), the observed hatching success on the Outer Banks was higher for plovers ( $86 \%$ of 120 nests hatched,

\section{Table 1}

List of intrinsic and extrinsic covariates tested for the potential effects on annual total counts of breeding pairs in shorebirds on the Outer Banks, 1989-2017.

\begin{tabular}{ll}
\hline & Data type \\
\hline $\begin{array}{l}\text { 1. Breeding climate (Mar-Aug) } \\
\text { Total precipitation }\end{array}$ & Continuous \\
$\begin{array}{l}\text { 2. Wintering climate (Oct-Feb) } \\
\text { Mean deviance of daily minimum temperature from the 25- } \\
\text { year mean }\end{array}$ & Continuous \\
$\quad$ Total precipitation & \\
3. Population productivity & Continuous \\
$\quad$ Average number of fledged chicks per pair & Continuous \\
4. Human disturbance & Continuous \\
Annual total counts of park visitors during Mar-Aug & Pesource management \\
Protection buffers on breeding activities & absence \\
6. Nesting habitat availability & \\
Total area size of dry sand habitat & Continuous \\
\hline
\end{tabular}

a Wintering locations are listed in Table 2. 
2008-2015; Kwon et al., 2018) than for oystercatchers (28\% of 1172 nests hatched, 1999-2008, Schulte and Simons, 2015; Stocking et al., 2017), whose main nest predators were ghost crabs and raccoons, respectively.

\subsection{Study area}

Breeding plovers and oystercatchers were monitored on the Outer Banks of North Carolina (USA), a 320-km long chain of barrier islands comprising Pea Island National Wildlife Refuge $\left(35.7129^{\circ} \mathrm{N}\right.$, $-75.4938^{\circ} \mathrm{W}$ ), Cape Hatteras National Seashore (Hatteras, $35.3036^{\circ} \mathrm{N}$, $-75.5114^{\circ} \mathrm{W}$ ) and Cape Lookout National Seashore (Lookout, $34.6052^{\circ} \mathrm{N},-76.5363^{\circ} \mathrm{W}$ ). In this study, we used the dataset from the two national seashores, both managed by the U.S. National Park Service (NPS). Since their establishment in 1953 (Hatteras) and 1966 (Lookout), the two parks have become popular tourist destinations, accommodating on average 2.4 and 0.4 million visitors a year, respectively (NPS, 2017). The two parks are separated by Ocracoke Inlet, a 1.6-km wide inlet between Ocracoke and Portsmouth islands. Despite close proximity of the two seashores, the breeding dispersal between the two seashores have not been reported for oystercatchers and was limited to $3 \%$ of confirmed breeders for plovers ( 3 out of 108, observed during 2015-2017). Highway 12 runs the length of Hatteras, and the associated engineered dune system reduces storm-induced breaches and washovers from creating new, early-successional habitats for nesting shorebirds (Paris and Mitasova, 2014). On the other hand, washovers are common on Lookout, where there is no human resident nor a highway nor an artificial dune system (Paris and Mitasova, 2014).

\subsection{Data collection}

NPS employees monitored breeding birds each year from early March when the shorebirds start forming pair bonds and making nest scrapes until chicks fledge. Potential shorebird nesting habitat was surveyed daily either by foot or in a vehicle for the length of both parks. Nests usually were found by observing the behavior of breeding pairs and were monitored every 1-5 days until the nest fate was determined. Plover and oystercatcher chicks are mobile within a day of hatching, and the NPS monitored them daily for survival until fledge (Weithman et al., 2020). The average number of fledged chicks per breeding pair has been the standard reproductive index used to monitor the productivity of each species and has been reported annually since 1992 (Hatteras) and 1989 (Lookout) for plovers and since 1999 (Hatteras) and 1998 (Lookout) for oystercatchers (Doshkov et al., 2018; USFWS, 2019).

Another standard index, and the response variable in our study, was the annual number of breeding pairs. Both species can and do renest multiple times when their nesting attempts fail at an early stage (i.e., eggs or young chicks). Accurate counts of the number of breeding pairs can be made when two conditions are met: 1) all birds are uniquely marked and identified on their nests and/or 2) all nests are found before hatch or failure. Breeding plovers were not banded prior to 2015 at either park, although breeding oystercatchers were banded since 2002. Before birds were individually identifiable, a newly found nest was considered to be a renest if: 1 ) it was initiated within the nesting territory of a recently failed nest, and 2) earlier observations did not indicate that another pair was present in the area. The intensive monitoring at our sites aimed to account for every breeding pair daily, and hence, minimized the uncertainty in pair counts. Breeding density was on average higher in Lookout than in Hatteras (plover: 0.1 vs. 0.03 pairs/ ha, oystercatcher: 0.2 vs. 0.1 pairs/ha, NPS, unpublished data).

\subsection{Potential drivers of population size}

\subsubsection{Population productivity}

Plovers often breed the spring following hatch whereas oystercatchers may skip 1-3 breeding seasons before they breed for the first time (McGowan et al., 2005a, 2005b; Saunders et al., 2014). We examined potential time-lags between reproduction and local recruitment by calculating the correlation coefficient between the total number of breeding pairs in year $y$ and the average number of fledglings per pair from year $y-i$ (for $i$ from 1 to 7 for oystercatchers and for $i$ from 1 to 2 for plovers). For all years monitored, plovers produced an average of 0.65 fledglings per pair $(S E=0.08)$ and 0.51 fledglings per pair $(S E=0.06)$ at Hatteras and Lookout respectively, and oystercatchers produced an average of 0.55 fledglings per pair $(\mathrm{SE}=0.07)$ and 0.36 fledglings per pair $(\mathrm{SE}=0.05)$ at Hatteras and Lookout respectively. The number of breeding pairs at year $y$ was most highly correlated with fledglings per pair from $y-6$ for oystercatchers at Lookout ( $r=0.73$ ), $y-3$ for oystercatchers at Hatteras $(r=0.75), y-1$ for plovers at Lookout $(r=0.42)$, and with no discernable correlation for plovers at Hatteras $(r=0.05)$. Therefore, we used the average number of fledglings per pair as the productivity covariate with 6-year time lag for oystercatchers at Lookout, 3-year for oystercatchers at Hatteras, and 1-year for both plover populations.

\subsubsection{Weather during breeding}

On the Outer Banks, weather-induced breeding failure was almost always caused by a storm event and subsequent flooding (NPS, unpublished data). Therefore, we examined the precipitation as an important variable. We obtained daily total precipitation $(\mathrm{mm})$ data for 1988-2017 from three weather stations: Cape Lookout $\left(34.60^{\circ} \mathrm{N}\right.$ $\left.76.54^{\circ} \mathrm{W}\right)$ and Cedar Island $\left(34.98^{\circ} \mathrm{N} 76.28^{\circ} \mathrm{W}\right)$ to represent weather conditions at Lookout and Hatteras Billy Mitchell $\left(35.23^{\circ} \mathrm{N} 75.68^{\circ} \mathrm{W}\right)$ to represent Hatteras. For each park, we calculated the total accumulated precipitation recorded from March 1 to August 31.

\subsubsection{Availability of nesting habitat}

We obtained Landsat 5 imagery for the Outer Banks (30-meter resolution) for all available years from 1989 to 2017 (USGS, https://earth explorer.usgs.gov). We used cloud-free images taken during Feb-Apr of each year to estimate the total area of dry sand (i.e., potential nesting habitat) that was available prior to each breeding season. In ArcGIS 10.4 (ESRI 2015, Redlands, CA, USA), we clipped each year's image to seven polygons or areas that included every plover and oystercatcher nest found at Hatteras and Lookout from 1989 to 2017 (Fig. 2). Focusing on these seven locations, we classified the land cover types into four categories: dry sand, wet sand, vegetation, and water. For each year's image, we generated 100 random points as reference points, which we manually classified into the four categories. Comparing the results of spectralbased classification to the manual classification confirmed that our mean classification accuracy was $95.7 \%$ (range: $91-100 \%$ ). The area of dry sand for each polygon and year was calculated as the number of pixels classified as 'dry sand'. We used the total area of dry sand (ha) as an index of nesting habitat availability for each year at each park.

\subsubsection{Recreational activity}

The seven breeding areas mostly consist of sandy beaches where recreational visitors and various activities such as dog walking and beach driving were permitted. We obtained the monthly total counts of recreational visitors at each park estimated by the NPS Statistics Office since 1988 (NPS, 2017). According to the Public Use Counting and Reporting Instructions published by the NPS (NPS, 1991, 1993), the recreational visitor counts at Hatteras were estimated from the number of vehicles counted either at the automatic traffic counter at the park's entrance or on a ferry, multiplied by the average number of persons per vehicle (between 1.7 and 2.7, depending on the month). In addition, the statistics included the number of private aircraft, multiplied by the persons-per-plane multiplier of 2.5, and since 1993, the number of registered hunters. Because Lookout was accessed only by boats or planes, the recreational visitor counts at Lookout were estimated based on the number of passengers on ferries and private boats and the number of visitors at the local museum and visitor centers. We used the sum of 
monthly visitor counts for March-August as an annual index of anthropogenic activities at the park.

\subsubsection{Protection management}

In response to apparent population declines of beach nesting species since the 1990s at both parks, the Interim Protected Species Management Strategy/Environmental Assessment ('Interim Strategy') proposed new regulations on off-road-vehicle use and beach recreation that have been in place since 2006 at Lookout and 2008 at Hatteras. The Interim Strategy provided protection buffers for breeding pairs, nests, and chicks of multiple species, including plovers and oystercatchers, within which off-road-vehicles or pedestrians were not allowed. The diameter of the protection buffers varied by species and year and ranged from $50-\mathrm{m}$ in diameter for plover nests up to 1000-m for unfledged plover chicks. Despite the variability in buffer sizes, the onset of the Interim Strategy marked the most substantial change in management of the two species during the time these data were collected. Thus, we created a categorical variable, which assigned years prior to the Interim Strategy as 'pre-' and years following the Interim Strategy as 'post-' protection. However, this designation does not indicate an absence of any protective measures prior to the Interim Strategy. At both parks, during the pre-protection years, nearly every plover nest was protected from potential predators with a predator exclosure since 1998, adhering to the species' recovery plan (USFWS, 1996), but oystercatcher nests were not exclosed. Furthermore, potential avian- and mammalian predators were removed from shorebird nesting habitat periodically during some of the monitored years. However, we could not account for the predator removal in our study because the data availability was inconsistent and incomplete across years.

\subsubsection{Weather at wintering sites}

We collected all available resight data on plovers and oystercatchers that had been captured and banded as breeders at either Hatteras or Lookout from data archives of the Virginia Tech Shorebird Program and the American Oystercatcher Working Group (Weithman et al., 2019, http://amoywg.org/). We assumed that a bird detected between Oct-Feb was at its wintering location. The southern Atlantic coast and the Bahamas, where the two species winter, are frequented with hurricanes during the birds' wintering period and can pose adult mortalities (Marsh and Wilkinson, 1991). Additionally, the relatively lower winter temperature can make the invertebrate prey less available and leave the shorebirds energetically stressed (Davidson, 1981; Johnson and Baldassarre, 1988; Mitchell et al., 2000; Schwemmer et al., 2014). Therefore, we further posited that the temperature as well as precipitation can affect the seasonal survival of birds.

Eighteen plovers that nested and were banded at Hatteras (8) and Lookout (10) were resighted on their wintering grounds (Table 2). All 18 plovers wintered in either the Bahamas (12) or Florida (6). Onehundred-ninety-eight oystercatchers from Hatteras (84) and Lookout (114) were resighted while on wintering grounds, and $14 \%$ and $28 \%$ of birds breeding at Hatteras and Lookout, respectively, remained on the Outer Banks during the winter (Table 2). In general, plovers from Outer Banks wintered at lower latitudes than oystercatchers, although the sample size was small for plovers (Fig. 2). For every location where at least one or more breeders from Hatteras and Lookout were resighted, we obtained daily minimum temperature and daily total precipitation data from nearby weather stations (Fig. S2). For birds breeding in year $y$, the relevant winter season ran through Oct-Dec of year $y-1$ and Jan-Feb of year $y$. The winter total precipitation was simply an accumulated daily total precipitation for each winter at each site ( $\left.\operatorname{Rain}_{\text {winter }}\right)$. We created a temperature index to represent the annual winter coldness at each location. For each day (Oct-Feb) in years 1989-2017, we estimated the deviance of the daily minimum temperature from the running 25-year mean of daily minimum temperatures for that day of the year $\left(\mathrm{T}_{\text {dev.25y }}\right)$. Temperature deviances were then averaged for each site and winter. Thus, $\mathrm{T}_{\text {dev.25y }}$ represents how much colder the given winter was
Table 2

Number of shorebirds banded as a breeder at Cape Hatteras and Cape Lookout National Seashores and resighted during Oct-Feb at the listed wintering locations during 2001-2017.

\begin{tabular}{|c|c|c|c|c|c|c|}
\hline \multirow[t]{3}{*}{ Species } & \multirow{3}{*}{\multicolumn{2}{|c|}{$\begin{array}{l}\text { Wintering location } \\
\text { State }\end{array}$}} & \multicolumn{4}{|c|}{ Original nesting location } \\
\hline & & & \multicolumn{2}{|c|}{ Hatteras } & \multicolumn{2}{|c|}{ Lookout } \\
\hline & & & $\mathrm{N}$ & $\%$ & $\mathrm{~N}$ & $\%$ \\
\hline \multirow{9}{*}{$\begin{array}{l}\text { American } \\
\text { oystercatcher }\end{array}$} & NC & Hatteras & 5 & 5.43 & 0 & 0.00 \\
\hline & NC & Lookout & 8 & 8.70 & 39 & 28.47 \\
\hline & NC & Wilmington & 5 & 5.43 & 7 & 5.11 \\
\hline & SC & Charleston & 22 & 23.91 & 32 & 23.36 \\
\hline & GA & Brunswick & 10 & 10.87 & 15 & 10.95 \\
\hline & FL & Cedar Key & 28 & 30.43 & 33 & 24.09 \\
\hline & FL & Fort Myers & 5 & 5.43 & 4 & 2.92 \\
\hline & FL & St. Augustine & 8 & 8.70 & 6 & 4.38 \\
\hline & NY & New Jersey ${ }^{\mathrm{a}}$ & 1 & 1.09 & 1 & 0.73 \\
\hline \multirow[t]{5}{*}{ Piping plover } & FL & Fort Myers & 2 & 25.00 & 1 & 10.00 \\
\hline & FL & Long Key & 0 & 0.00 & 1 & 10.00 \\
\hline & FL & Tampa & 0 & 0.00 & 1 & 10.00 \\
\hline & FL & Highland Beach & 1 & 12.50 & 0 & 0.00 \\
\hline & & The Bahamas & 5 & 62.50 & 7 & 70.00 \\
\hline
\end{tabular}

${ }^{\text {a }}$ Excluded from analysis as we considered the record an outlier.

in comparison to the past 25 years at each wintering site. Representative values of our two wintering climate indices (Rain winter $_{\text {dev.25y }}$ ) for each population in any given year were calculated as a weighted average across all wintering locations, with the banded population's proportional use of each wintering location (all years pooled) as the weight. The wintering climate indices were standardized across years and sites prior to calculating the weighted average.

Prior to analyses, we examined for potential multicollinearity among explanatory variables by 1 ) checking the correlation matrix and 2) calculating a variation inflation factor (VIF) for each predictor (Zuur et al., 2010). The visitor counts were not correlated with protection (categorical: yes vs. no, $\mathrm{r}=-0.012, \mathrm{p}=0.93$ ), but were correlated with the habitat availability $(r=0.38, \mathrm{p}<0.01)$. Both winter temperature proxies (mean $5 \%$ daily minimum temperature and mean deviance of daily minimum temperature from the 25-year mean) were correlated with NAO index $(r=0.40, p<0.01$ and $r=0.42, p<0.01$, respectively). However, the variance inflation factors for all explanatory variables in a global model were less than 3.1, indicating a limited multicollinearity.

\subsection{Data analyses}

\subsubsection{Model structure}

We developed hierarchical linear models in a Bayesian framework to estimate effects of all covariates (Table 1 ) on the annual total counts of breeding pairs. We had 18 years of data for oystercatchers and 26 years of data for plovers. Thus, we built our models to fit to data for each species separately with a random effect for site (i.e., park), so that we use the full length of the time series. All covariates were standardized across the two parks but within each species. The population productivity estimates were missing for oystercatchers during the first 3 years at Hatteras and the first 5 years at Lookout, and these missing values were replaced with the mean values for all other years (using the mean values did not affect the resultant parameter estimates, see Fig. S3). In addition to the set of covariates listed in Table 1 , we tested the linear and quadratic effect of year to capture any temporal trend in population size that is not explained by our set of covariates.

At each park and for each species, we took the number of breeding pairs at the first year of monitoring as our initial abundance $(N)$. From the second through the last year of monitoring, our $N$ at year $y+1$ was then estimated as:

$N[s, y+1] \sim \alpha[s]+\delta[s] \times N[s, y]+\beta_{1}[s] \times \operatorname{Var}_{1}[s, y+1]+\cdots+\beta_{n}[s] \times \operatorname{Var}_{n}[s, y+1]$, 
where $s$ denoted park, and $n$ denoted the number of covariates included in the model. Thus, our models estimated $N$ at year $y+1$ as a function of a site-specific intercept $(\alpha), N$ at year $y(\delta)$, and the effects of a set of covariates $(\beta)$. We used uninformative normal priors with mean 0 and precision 0.001 for $\alpha$ and $\delta$ in the above equation. For the effects of the covariates $\left(\beta_{1 \sim \mathrm{n}}\right)$, we specified the Bayesian Lasso regression parameters with the Laplace distribution with species specific error terms (Park and Casella, 2008).

\subsubsection{Model fitting \& comparison}

We executed the Bayesian models in JAGS v. 4.3.0 (Plummer, 2003) through the package 'jagsUI' (Kellner, 2017) in R v. 4.0.2 (R Core Team, 2020). We discarded estimates from an adaptation period of 50,000 iterations and a burn-in period of 50,000 iterations to ensure adequate mixing across three chains. We ran each model for a further 100,000 iterations and saved the output from every fifth iteration to avoid autocorrelation, resulting in 20,000 estimates to generate posterior distributions of parameters. For each model run, we checked the convergence in two ways: a visual check of the trace plot and the Gelman-Rubin statistics $<1.1$ for all estimates of model parameters (Brooks and Gelman, 2012).

Bayesian model selection is an emerging field and offers multiple approaches for model comparison and multimodel inference (Hooten and Hobbs, 2015). We used the leave-one-out cross-validation (LOO) for model evaluation, which provides point estimates and standard errors of the expected log pointwise predictive density and an information criterion looic (the point estimate converted to deviance scale; $\mathrm{R}$ package 'loo', Vehtari et al., 2017, 2018). We used the final model with the lowest looic to generate estimates for the mean predicted annual total counts of breeding pairs and the effect of each covariate, as well as the

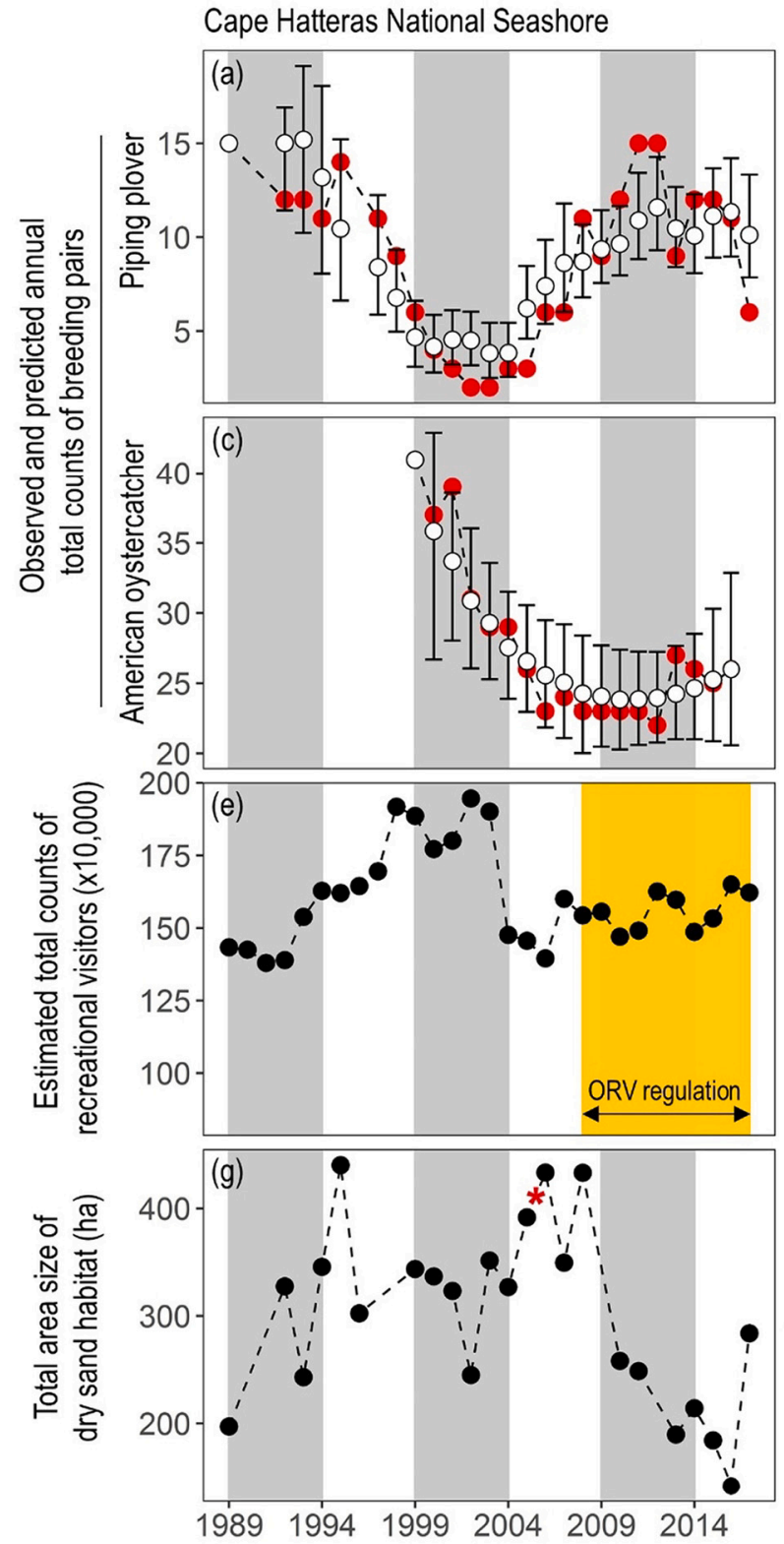

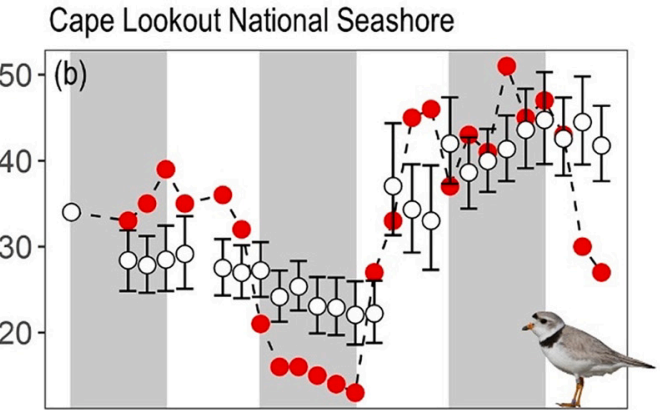
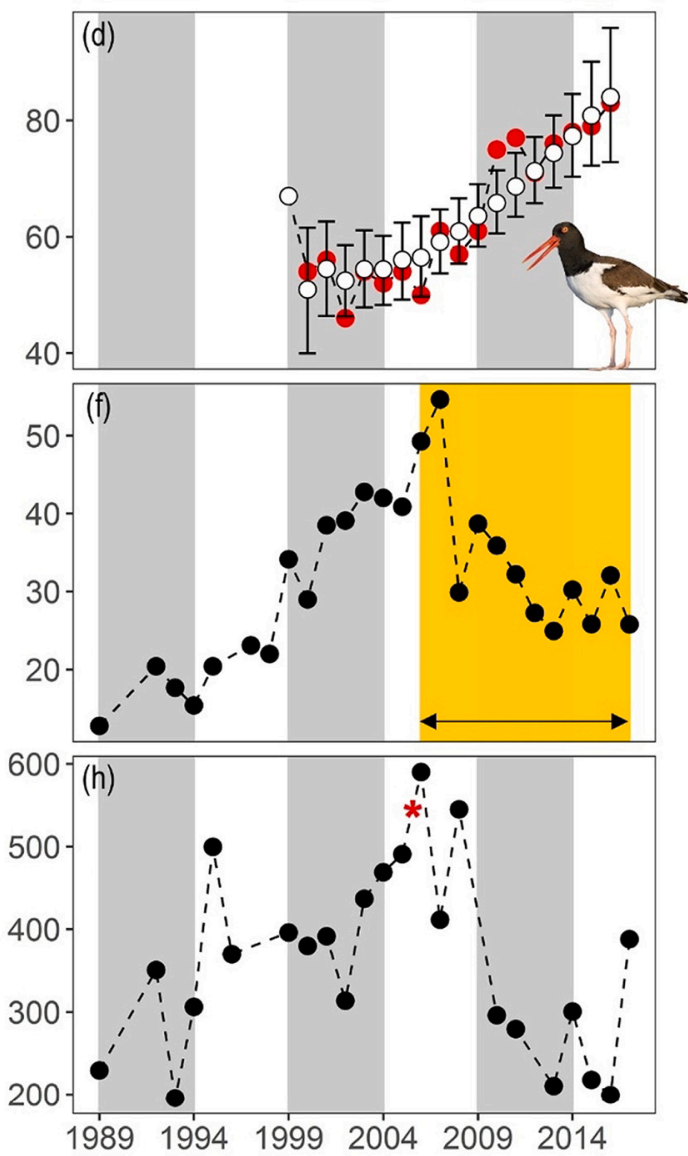

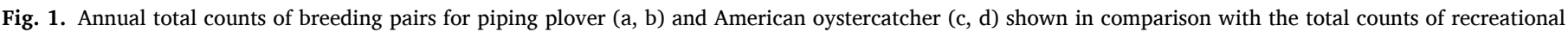

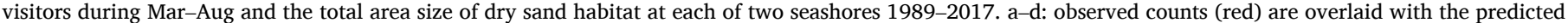

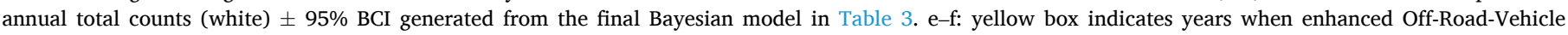

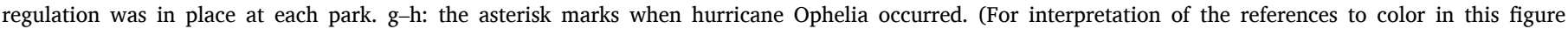
legend, the reader is referred to the web version of this article.) 
95\% Bayesian credible interval (BCI) from the posterior distribution for each estimate.

\section{Results}

From 1989 to 2015, an average of $9(\mathrm{SD}=4.3$, range $=2-15)$ and 33 $(11.3,13-51)$ breeding pairs of plovers and $28(5.8,22-41)$ and 65 $(12.0,46-83)$ breeding pairs of oystercatchers nested each year at Hatteras and Lookout, respectively. The trend in breeding plover pairs was similar between the two parks with a steep decline between the mid1990s and early-2000s followed by a recovery in population sizes (Fig. 1a, b). Oystercatcher populations, however, showed opposite trends at the two parks (Fig. 1c, d). For oystercatchers at Hatteras, the change in pair counts between subsequent years was smaller when population size was bigger (Figs. 3b and S4). The average number of fledglings per pair decreased with increasing number of breeding pairs for oystercatchers at Hatteras (Fig. S5).

Table 3 summarizes models that converged on the subset of data for piping plover (a) and American oystercatcher (b). For plovers, the top model suggested there was a positive correlation with protection $(95 \%$ BCI $=0.039-0.318$ for Hatteras and $0.291-0.709$ for Lookout) and negative correlation with visitor counts on the number of breeding pairs at both parks ( $95 \% \mathrm{BCI}=-0.355$ to -0.082 for Hatteras and -0.207 to -0.020 for Lookout; Table 3; Fig. 4a). For oystercatchers, however, none of the variables explained the annual variation in the number of breeding pairs (Fig. 4b, also see trace plots in Figs. S7 \& S8).

Dry sand habitat area fluctuated threefold in both parks across years (Hatteras: 141.5-440.1; Lookout: 195.3-590.1 in ha), with a significant quadratic effect of year $\left(\beta_{\text {year } 2}=-0.93, t=-4.68, p<0.001\right.$; Fig. $1 \mathrm{~g}$, h). Total rainfall during Mar-Aug was similar between two parks ( $\beta_{\text {park }}$ $=0.43, \mathrm{t}=1.81, \mathrm{p}=0.07$; Fig. S9a). However, none of the models including the dry sand habitat area converged nor did we find effect of wintering climate on the annual variation in population size.

\section{Discussion}

Our results suggest a strong correlation between the anthropogenic environment during the breeding season on plover populations in the Outer Banks and less of an effect from the conditions outside of the breeding grounds. However, sympatric populations of oystercatchers showed opposite population trends at two parks that were not explained by any of our covariates, despite similar ecological niches to piping plovers. Pinpointing the main driver of a population trajectory often is difficult, because a number of intrinsic and extrinsic factors can simultaneously contribute to the annual changes in population size (Bjørnstad and Grenfell, 2001; Saunders et al., 2018). However, our relatively simple model with just two covariates, protection and visitor, closely predicted the annual changes in plover pair counts (see Fig. 1a). The fact

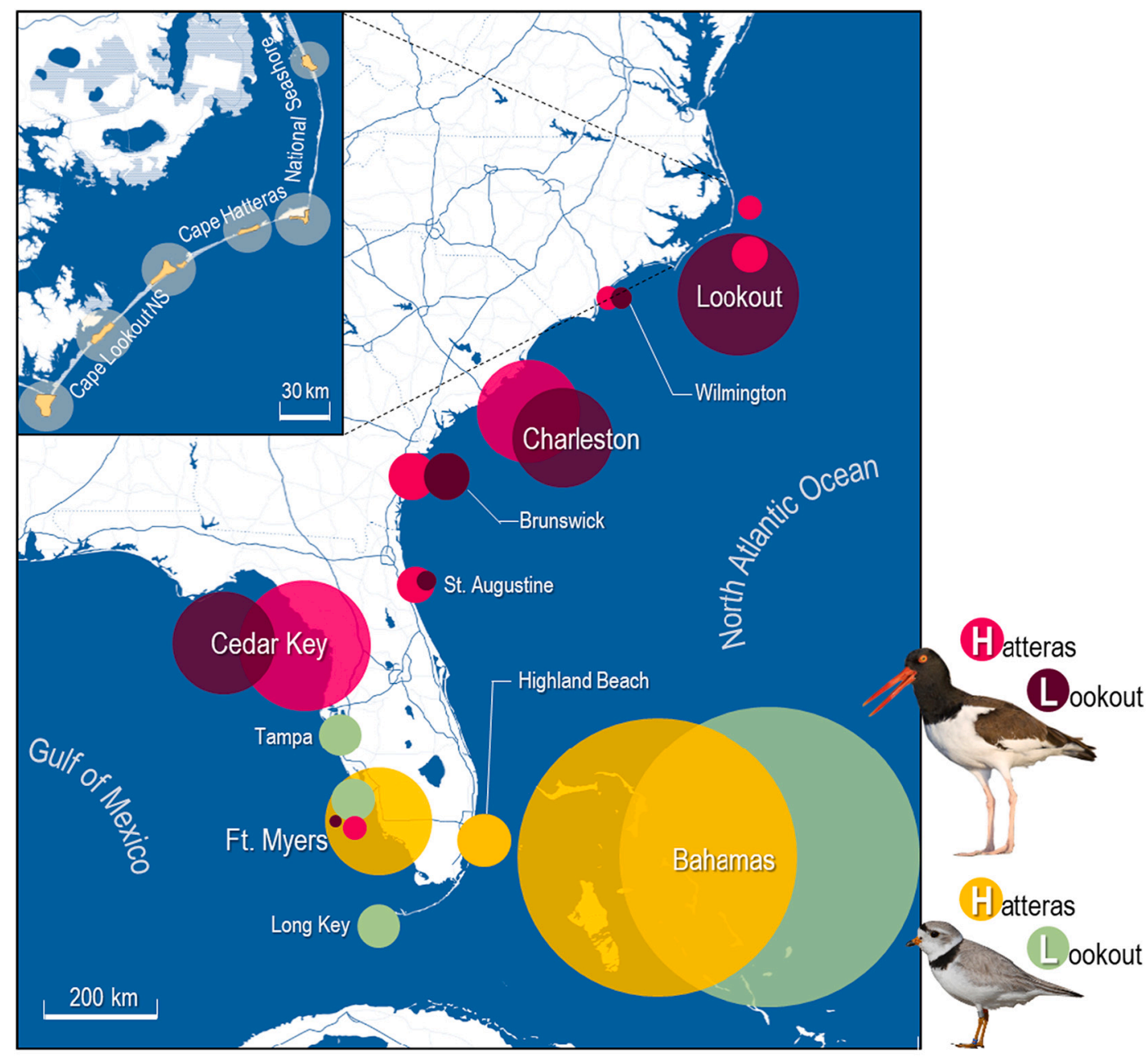

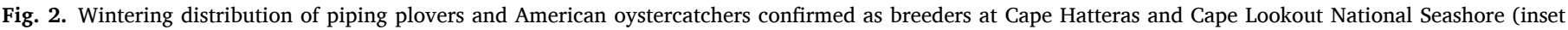

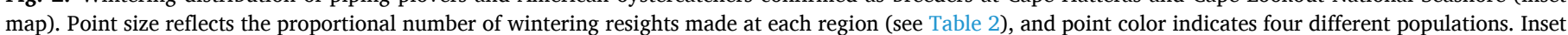

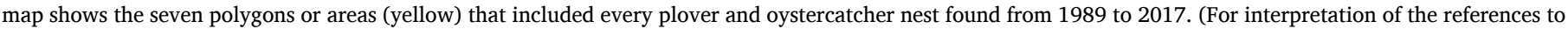
color in this figure legend, the reader is referred to the web version of this article.) 


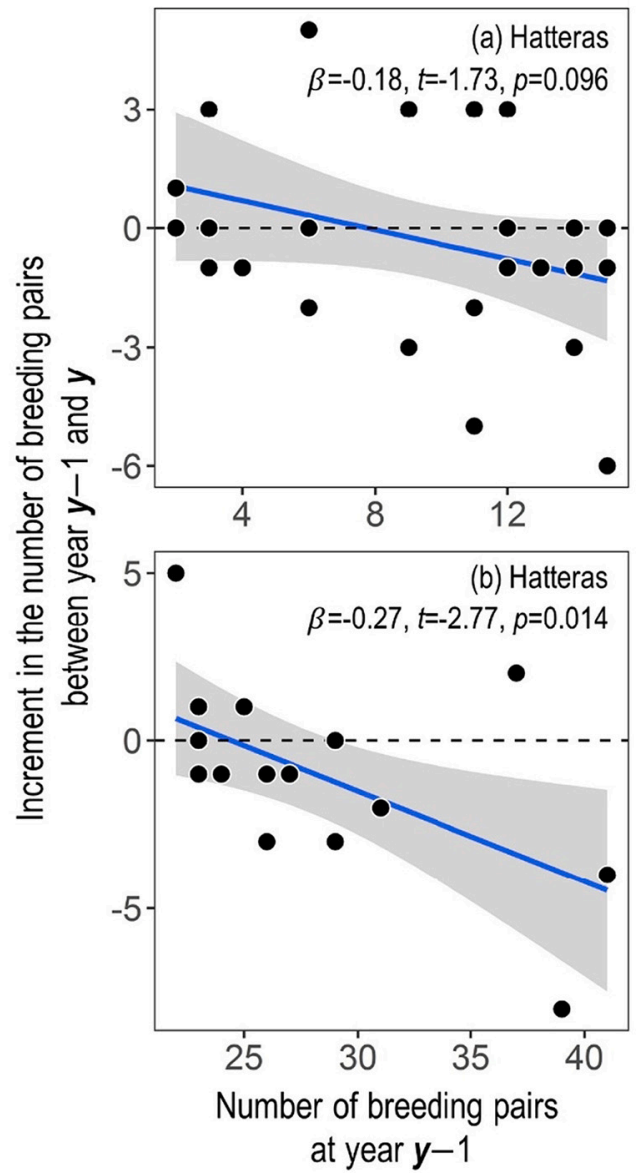

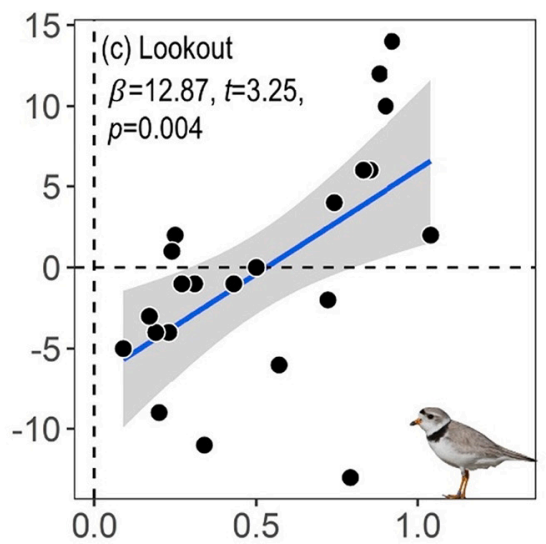

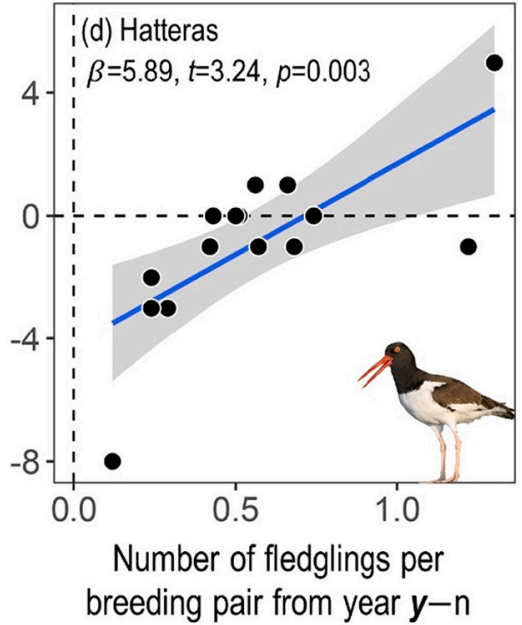

Fig. 3. Relationship of the total number of breeding pairs from previous year (a, b) and the average number of fledglings produced per breeding pair from $n$ years ago (c, d) with the increment in pair count observed between the current and previous year, for piping plover $(a, c)$ and American oystercatcher (b, d) at two seashores during 1989-2017. Regression line from a simple linear regression model $(\mathrm{y} \sim \mathrm{x})$ is fitted with the $95 \%$ confidence interval. $n$ $=3$ years for oystercatchers at Hatteras and 1 for both plover populations.

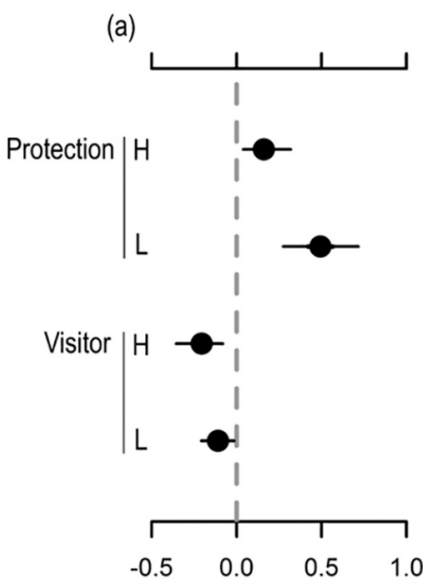

Parameter Estimate (b)

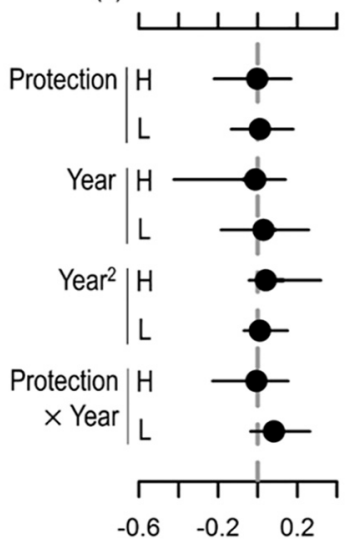

Parameter Estimate

Fig. 4. Standardized effect size of supported covariates on the annual total number of breeding pairs estimated from the Bayesian model fitted to (a) plover-only or (b) oystercatcher-only. Error bars indicate 95\% Bayesian credible intervals and significant effect of the covariate when not overlapping zero. Each model included park (H: Hatteras, L: Lookout) as a random effect.

that our model predicted the plover pair counts better at Hatteras than at Lookout supports our prediction that the correlation with visitor counts would be stronger at Hatteras, where the visitor counts were five times higher than those observed at Lookout.

Direct impact of human presence on reproductive behavior and reproductive output has been previously shown with piping plovers

Table 3

A set of Bayesian models fitted and successfully converged on the subset of data for (a) piping plover and (b) American oystercatcher. Response variable was the annual total number of breeding pairs. Random effect of park was included in each model. Looic is an information criterion, estimated as the expected predictive accuracy based on leave-one-out cross-validation multiplied by -2 . Smaller looic values suggest higher predictive accuracy (Vehtari et al., 2017). Missing looic value indicates that the model did not converge.

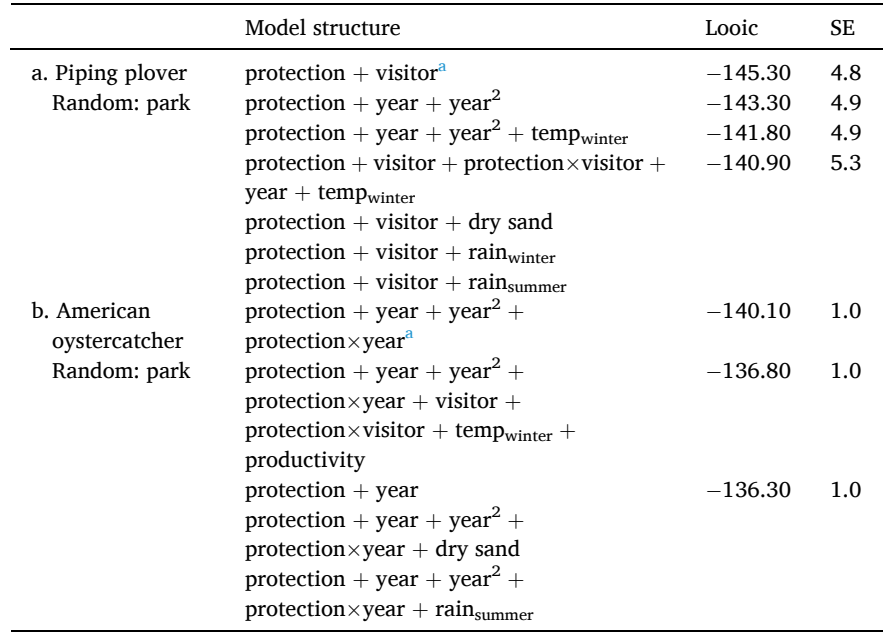

${ }^{\mathrm{a}}$ Final models used to predict the annual total counts of breeding pairs shown in Fig. 1. 
(DeRose-Wilson et al., 2018) and American oystercatchers (McGowan and Simons, 2006; Sabine et al., 2008; Felton et al., 2018). Although one study showed that the vigilance of oystercatcher parents was higher during brooding than during incubation (Sabine et al., 2008), a seasonal change in sensitivity to disturbance is yet to be examined further. Another study showed a local-scale redistribution of breeding oystercatchers on the barrier beaches of New Jersey, triggered by the intensity of human disturbance and beach-driving (Virzi, 2010). At a population level, protection measures have increased population size in snowy plovers (Charadrius nivosus; Lafferty et al., 2006), and oystercatcher adult survival rates increased with reduced disturbance (West et al., 2002; Gibson et al., 2018). These studies used either a direct observation of human presence near birds to parameterize the anthropogenic disturbance (McGowan and Simons, 2006; Sabine et al., 2008; Felton et al., 2018) or a categorical variable for varying degrees of human disturbance based on educated decisions (Virzi, 2010; DeRose-Wilson et al., 2018). In the absence of direct measures on human disturbance, we assumed the annual total counts of park visitors during shorebirds' breeding season was a reasonable proxy for visitor density on beaches and hence the degree of potential human disturbance to shorebirds.

It is likely that some visitors counted at Hatteras never went into shorebird habitat, but instead used other regional amenities including restaurants, gift ships, and boat charters. A small number may have simply driven through, but we suspect this was rare, as highway 12 is an inefficient route between places outside of the park. The top six selfidentified activities of park visitors were, in descending order of time spent, fishing, sunbathing, swimming, beach driving, lighthouse visiting, shell collecting (Cape Hatteras National Seashore, unpublished data), activities which would likely have put visitors in potential shorebird habitat. Therefore, we believe the visitor counts used in our study were a reasonable index of visitor density on beaches, which is likely correlated with numbers of people in shorebird habitat.

Our study suggests that, at least for plovers, potential human disturbance and protective measures affected breeding abundances. Gill (2007) summarized that a population-level impact of human disturbance occurs either through density-dependent changes in demography or through a spatial redistribution following a long-term avoidance of disturbed areas. Given that most direct human disturbance to breeding shorebirds is prevented with protection buffers on the Outer Banks (Weithman et al., 2020), the negative correlation between visitor counts and breeding abundance we observed may arise as the indirect effects of growing visitor population limiting the availability of suitable breeding habitat. In fact, our results from Hatteras indicate density-dependence in the annual fluctuation of population size for both species and the annual fecundity of oystercatchers, suggesting that the Hatteras populations of both species are at carrying capacity. On the other hand, Weithman et al. (2019) showed that the reproductive output of plover population on the Outer Banks has been consistently lower than that needed for a stationary population and concluded that population growth of plovers on the Outer Banks likely relies on immigration. Therefore, it also is possible that the negative correlation between visitor counts and breeding abundance we observed is an indirect effect of growing visitor population on slowed immigration of new breeders. In a growing population in New York, the number of immigrants had, among demographic variables, the most important effect on population growth rate (Robinson et al., 2020). Moreover, at least 8 cases of piping plover population irruptions after storms created new habitat suggest that this species often is at or near carrying capacity (Robinson et al., 2019).

Visitor density and distribution on beaches may determine the 'realized habitat' for nesting shorebirds (Maslo et al., 2018). However, the absolute amount of nesting habitat (i.e., areas of dry sand) on barrier islands is dependent on natural processes such as washovers. Populations of beach-nesting shorebirds naturally fluctuate to some extent following the habitat creation by storm events and subsequent vegetation succession (Convertino et al., 2011; Hunt et al., 2018; Robinson et al., 2019). Since plover monitoring began in 1989, at least 14 major hurricanes have affected the Outer Banks (see Figs. S10 and S11), among which, hurricanes Isabel (Sep 2003), Ophelia (Sep 2005), and Matthew (Oct 2016) were the most damaging to human infrastructure. Monthslong recovery of infrastructure followed Hurricane Isabel at Hatteras Island, which did not increase the overall size of dry sand habitat, but the storm may have significantly decreased the visitor counts the following summer in 2004 (see Fig. 1). Two years later, Hurricane Ophelia added 99 ha of dry sand habitat to Lookout and 41 ha to Hatteras, and the hurricane-induced overwashes created easier access to the bayside foraging habitat at Lookout (Robinson et al., 2019). These two major hurricanes coincided with the significant increase of plovers at both parks (see Figs. S10 and S11), corroborating the idea that the species is adapted to quickly respond to changing habitat availability (Cohen et al., 2009; Catlin et al., 2015; Hunt et al., 2018; Robinson et al., 2019). However, the years hurricanes increased the total amount of dry sand habitat at Hatteras (2002-2006) coincided with substantially decreased visitor counts at the park, which makes it difficult to separate the impacts from these potential drivers. At Lookout, however, plover counts continued to increase despite increased visitor counts during 2004-2007, suggesting that habitat expansion played an important role in population growth. It is likely that both habitat and visitor counts play a part in affecting local breeding populations.

Overall, our results suggested strong correlation between the forcing of the anthropogenic environment and the population trajectories of plovers on the Outer Banks, but not for oystercatchers. Because the extrinsic environment for breeding and wintering was similar for oystercatchers breeding at both parks, the observed discrepancy in population trajectories may have stemmed from different demographic rates at the two parks. For example, our results indicated that the park-level productivity (i.e., the number of fledglings produced per breeding pair) had a strong linear relationship with the annual increment on the number of breeding pairs for oystercatchers at Hatteras but not at Lookout (see Fig. S6c, d). Sightings of locally hatched oystercatcher chicks returning as breeders support the idea that the oystercatcher population growth at Hatteras may mainly rely on local recruitment albeit the small sample sizes ( 7 out of 15 chicks from 2004 and 3 out of 9 chicks from 2005 returned to the park to breed; NPS, 2009). At the same time, oystercatcher population growth slowed and productivity decreased as the number of pairs increased at Hatteras, suggesting a density-dependent control of the population size (see Figs. 3b and S4c). From our observations, we can further hypothesize that the oystercatcher population at Hatteras has declined, as opposed to the plovers at both parks or oystercatchers at Lookout, because 1) local productivity and recruitment has been low at Hatteras since 2002 or 2) the oystercatcher population at Hatteras exceeded carrying capacity some time before 2002. A previous study at Lookout showed that the productivity of oystercatchers greatly improved following Hurricane Isabel in 2004, which was attributed to decreased number of predators on the islands, where the lack of engineered dunes allowed overwashes (Schulte and Simons, 2016). From 2003 to 2004, the probability of an oystercatcher nest surviving to hatch increased from the baseline rate of 0.17 to 0.77 (Schulte and Simons, 2016), and the productivity also increased from 0.15 to a historic high of 0.87 fledglings per pair (this study), which was correlated with the immigration of 14 new breeding pairs 6 years later in 2010. At Hatteras, however, we did not see a similar improvement in productivity until 2010 .

Although our results hinted at the potential density-dependency of population increase for both species at Hatteras, it is difficult to test if the shorebird populations on the Outer Banks have reached carrying capacity. Previous studies on Eurasian and African oystercatchers have shown that a fluctuation in population sizes can arise due to densitydependent territory establishment and competition or densitydependent adult mortality (Goss-Custard et al., 1995; Loewenthal et al., 2015). As the oystercatcher population at Lookout continues to grow, continued monitoring efforts will be essential to understanding what limiting factors are affecting their populations. 
Two other major population drivers not addressed in our study are food availability and predation. As oystercatchers and plovers have distinctive diets, we can expect any demographic impact from food availability to be shared within the species across two parks. Although oystercatchers, being a diet specialist, are expected to be more sensitive to food availability, it is unlikely that the local bivalve abundances led the opposite population trajectories seen with oystercatchers at two parks. On the other hand, we can expect any demographic impact from predation to be shared across species within each park. Hatteras Island was first connected to the northern parts of the Outer Banks by a bridge built in 1963, and the first appearance of red fox coincides with the initial decrease in the plover population at Hatteras (1996). Moreover, the period of plover population recovery also coincides with a largescale National Park Service predator management effort at Hatteras (ca. 1400 mammalian predators removed during 2002-2009 (NPS, unpublished data)). Thus, perhaps unsurprisingly, mesocarnivore presence may partially shape the long-term population trajectories of shorebirds on the Outer Banks (Stocking et al., 2017). However, systematic sampling and estimation of predation impacts on plovers and oystercatchers are needed to assess this hypothesis (Hunt et al., 2019).

Our models showed a biologically significant correlation between human density and protective measures and the long-term population trajectory of beach-nesting shorebirds. Our study provides a conclusive evidence for strong anthropogenic effect of both disturbance and protection on the population trajectory of plovers, because our study could simultaneously examine multiple drivers using three-decades long data. However, the complex response of four different populations could be fully explained only when we considered the stochastic changes in habitat availability and predation risks partly related to two hurricanes, Isabel and Ophelia. Within national parks, the adaptive management paradigm can introduce an additional layer of stochasticity in terms of the frequent changes in the intensity of protection measures applied. However, unlike natural stochasticity such as storm events, the management actions can be controlled and should be designed to combine long-term monitoring with adaptive, long-term experiments (Krebs, 1991; Brown et al., 2001).

\section{CRediT authorship contribution statement}

Eunbi Kwon: Methodology, Formal analysis, Writing - Original draft, Samantha Robinson: Data curation, Formal analysis, Writing - Review \& editing,

Chelsea E. Weithman: Investigation, Data curation, Writing - Review \& editing,

Daniel H. Catlin: Writing - Review \& editing, Supervision,

Sarah M. Karpanty: Writing - Review \& editing, Supervision,

Jon Altman: Investigation, Writing - Review \& editing, Data curation,

Theodore R. Simons: Writing - Review \& editing, Supervision, Project administration,

James D. Fraser: Methodology, Writing - Review \& editing, Supervision, Project administration, Funding acquisition.

\section{Declaration of competing interest}

The findings and conclusions in this article are those of the author(s) and do not necessarily represent the views of the National Park Service. Any use of trade names is for descriptive purposes only and does not imply endorsement by the US Government. We do not have any conflict of interest to declare.

\section{Acknowledgements}

We thank all lead technicians for being integral part of field data collection and numerous field technicians who have collected data at Cape Hatteras National Seashore and Cape Lookout National Seashore over the years. Banding and monitoring of American Oystercatchers at both seashores was led by former graduate students, Tracy Borneman, Melissa Davis, Shilo Felton, Nathan Hostetter, Conor McGowan, Eli Rose, Shiloh Schulte, and Jessica Stocking. We also thank numerous contributors who reported the resightings of banded Piping Plovers and American Oystercatchers during non-breeding seasons; especially, Felicia Sanders and Mark Spinks (Charleston, SC), Tim Keyes (Brunswick, GA), Pat Leary, Doris Leary, Janell Brush, and Marianne Korosy (Cedar Key \& St. Augustine, FL), Lee County Bird Patrol and Charlie Ewell (Fort Myers, FL).

\section{Funding statement}

Research support was provided by the National Park Service at Cape Hatteras National Seashore. No funders had any input into the content of the manuscript nor required their approval of the manuscript before submission or publication.

\section{Ethics statement}

Field monitoring of piping plovers and American oystercatchers was approved by the Endangered Species Permit issued from North Carolina Wildlife Resources Commission (permit number 16-ES00197).

\section{Appendix A. Supplementary data}

Supplementary data to this article can be found online at https://doi. org/10.1016/j.biocon.2021.109178.

\section{References}

Barbraud, C., Weimerskirch, H., 2001. Emperor penguins and climate change. Nature $411,183-186$.

Baudains, T.P., Lloyd, P., 2007. Habituation and habitat changes can moderate the impacts of human disturbance on shorebird breeding performance. Anim. Conserv. $10,400-407$.

Bjørnstad, O.N., Grenfell, B.T., 2001. Noisy clockwork: time series analysis of population fluctuations in animals. Science 293, 638-643.

Brooks, S.P., Gelman, A., 2012. General methods for monitoring convergence of iterative simulations. J. Comput. Graph. Stat. 7, 434-455.

Brown, J.H., Whitham, T.G., Ernest, S.K.M., Gehring, C.A., 2001. Complex species interactions and the dynamics of ecological systems: long-term experiments. Science $293,643-650$

Catlin, D.H., Fraser, J.D., Felio, J.H., 2015. Demographic responses of piping plovers to habitat creation on the Missouri river. Wildl. Monogr. 192, 1-42.

Catlin, D.H., Gibson, D., Hunt, K.L., Friedrich, M.J., Weithman, C.E., Karpanty, S.M., Fraser, J.D., 2019. Direct and indirect effects of nesting density on survival and breeding propensity of an endangered shorebird. Ecosphere 10, e02740.

Cohen, J.B., Houghton, L.M., Fraser, J.D., 2009. Nesting density and reproductive success of piping plovers in response to storm- and human-created habitat changes. Wildl. Monogr. 173, 1-24.

Convertino, M., Elsner, J.B., Muñoz-Carpena, R., Kiker, G.A., Martinez, C.J., Fischer, R. A., Linkov, I., 2011. Do tropical cyclones shape shorebird habitat patterns? Biogeoclimatology of snowy plovers in Florida. PLoS One 6, e15683.

Davidson, N.C. 1981. Survival of shorebirds (Charadrii) during severe weather: the role of nutritional reserves. In Feeding and Survival Strategies of Estuarine Organisms, N. V. Jones, and W.J. Wolff, eds. (Boston, MA: Springer US), pp. 231-249.

DeRose-Wilson, A.L., Hunt, K.L., Monk, J.D., Catlin, D.H., Karpanty, S.M., Fraser, J.D., 2018. Piping plover chick survival negatively correlated with beach recreation. J. Wildl. Manag. 82, 1608-1616.

Doshkov, P., Losch, K., Thompson, W., Wright, J., and Rhodes, A. 2018. Shorebird monitoring and management at Cape Hatteras National Seashore: 2017 annual report. Natural Resource Report NPS/CAHA/NRR-2018/XXX. National Park Service, Fort Collins, Colorado.

Douglass, N.J., Gore, J.A., Paul, R.T., 2001. American oystercatchers nest on gravel covered roofs in Florida. Florida Field Naturalist 29, 75-80.

Dowding, J.E., Murphy, E.C., 2001. The impact of predation by introduced mammals on endemic shorebirds in New Zealand: a conservation perspective. Biol. Conserv. 99, 47-64.

Dowling, B., Weston, M.A., 1999. Managing a breeding population of the Hooded Plover Thinornis rubricollis in a high-use recreational environment. Bird Conserv. Int. 9, 255-270.

Dundas, S.J., von Haefen, R.H., Mansfield, C., 2016. Recreation costs of endangered species protection: evidence from Cape Hatteras National Seashore. Mar. Resour. Econ. 33, 1-25.

Elias, S., Fraser, J., Buckley, P., 2000. Piping plover brood foraging ecology on New York Barrier Islands. J. Wildl. Manag. 64, 346-354. 
Elliott-Smith, E., and Haig, S.M. 2004. Piping plover (Charadrius melodus). The Birds of North America. (P. G. Rodewald, Editor). Cornell Lab of Ornithology, Ithaca, NY, USA. DOI: https://doi.org/10.2173/bna.2.

Felton, S.K., Pollock, K.H., Simons, T.R., 2018. Response of beach-nesting American oystercatchers to off-road vehicles: an experimental approach reveals physiological nuances and decreased nest attendance. Condor 120, 47-62.

Forcada, J., Trathan, P.N., Reid, K., Murphy, E.J., Croxall, J.P., 2006. Contrasting population changes in sympatric penguin species in association with climate warming. Glob. Chang. Biol. 12, 411-423.

Gibson, D., Chaplin, M.K., Hunt, K.L., Friedrich, M.J., Weithman, C.E., Addison, L.M., Cavalieri, V., Coleman, S., Cuthbert, F.J., Fraser, J.D., Golder, W., Hoffman, D., Karpanty, S.M., Catlin, D.H., 2018. Impacts of anthropogenic disturbance on body condition, survival, and site fidelity of nonbreeding piping plovers. Condor 120, 566-580.

Gill, J.A., 2007. Approaches to measuring the effects of human disturbance on birds. Ibis $149,9-14$.

Gill, J., Norris, K., Sutherland, W., 2001. Why behavioral responses may not reflect the population consequences of human disturbance. Biol. Conserv. 97, 265-268.

González-Braojos, S., Sanz, J.J., Moreno, J., 2017. Decline of a montane Mediterranean pied flycatcher Ficedula hypoleuca population in relation to climate. J. Avian Biol. 48 1383-1393.

Goss-Custard, J.D., Caldow, R.W.G., Clarke, R.T., Durell, S.E.A.L.V.D., Urfi, J., West, Y. D., 1995. Consequences of habitat loss and change to populations of wintering migratory birds: predicting the local and global effects from studies of individuals. Ibis 137, S56-S66.

Grenfell, B.T., Wilson, K., Finkenstädt, B.F., Coulson, T.N., Murray, S., Albon, S.D., Pemberton, J.M., Clutton-Brock, T.H., Crawley, M.J., 1998. Noise and determinism in synchronized sheep dynamics. Nature 394, 674-677.

Gunnarsson, T.G., Gill, J.A., Petersen, A., Appleton, G.F., Sutherland, W.J., 2005. A double buffer effect in a migratory shorebird population. J. Anim. Ecol. 74, 965-971.

Harrison, X.A., Blount, J.D., Inger, R., Norris, D.R., Bearhop, S., 2011. Carry-over effects as drivers of fitness differences in animals. J. Anim. Ecol. 80, 4-18.

Hooten, M.B., Hobbs, N.T., 2015. A guide to Bayesian model selection for ecologists. Ecol. Monogr. 85, 3-28.

Hsieh, C., Ohman, M.D., 2006. Biological responses to environmental forcing: the linear tracking window hypothesis. Ecology 87, 1932-1938.

Hunt, K.L., Fraser, J.D., Friedrich, M.J., Karpanty, S.M., Catlin, D.H., 2018. Demographic response of piping plovers suggests that engineered habitat restoration is no match for natural riverine processes. Condor 120, 149-165.

Hunt, K.L., Karpanty, S.M., Davis, K.L., Wilke, A., Myers, N., Spiegel, C., Schulte, S. Catlin, D.H., Fraser, J.D., 2019. Guidance and Best Practices for Coordinated Predation Management to Benefit Temperate Breeding Shorebirds in the Atlantic Flyway. In: U.S. Fish and Wildlife Service and National Fish and Wildlife Foundation.

Jenouvrier, S., Barbraud, C., Weimerskirch, H., 2005. Long-term contrasted responses to climate of two Antarctic seabird species. Ecology 86, 2889-2903.

Johnson, C., Baldassarre, G., 1988. Aspects of the wintering ecology of piping plovers in coastal Alabama. Wilson Bull. 100, 214-223.

Kellner, K., 2017. jagsUI: a wrapper around 'rjags' to streamline 'JAGS' analyses. R package version 1.4.9. https://CRAN.R-project.org/package=jagsUI.

Koch, S.L., Paton, P.W.C., 2014. Assessing anthropogenic disturbances to develop buffer zones for shorebirds using a stopover site. J. Wildl. Manag. 78, 58-67.

Krebs, C.J., 1991. The experimental paradigm and long-term population studies. Ibis $133,3-8$

Kwon, E., Fraser, J.D., Catlin, D.H., Karpanty, S.M., Weithman, C.E., Muiznieks, B., 2018. Presence of ghost crabs and piping plover nesting success. J. Wildl. Manag. 82, 850-856.

Lafferty, K.D., Goodman, D., Sandoval, C.P., 2006. Restoration of breeding by snowy plovers following protection from disturbance. Biodivers. Conserv. 15, 2217-2230.

Lauro, B., Burger, J., 1989. Nest-site selection of American oystercatchers (Haematopus palliatus) in salt marshes. Auk 106, 185-192.

Loewenthal, D., Paijmans, D.M., Hockey, P.A., 2015. Year-round territoriality in longlived birds: rethinking the concept of carrying capacity. Ostrich 86, 23-34.

Mansfield, C., Loomis, R., and Braun, F. 2011. Benefit-Cost Analysis of Proposed ORV Use Regulation in Cape Hatteras National Seashore (Denver: National Park Service, Final Report, January).

Marsh, C.P., and Wilkinson, P.M. 1991. The impact of hurricane Hugo on coastal bird populations. J. Coast. Res. 1991, 327-334.

Maslo, B., Leu, K., Pover, T., Weston, M.A., Schlacher, T.A., 2018. Managing birds of conservation concern on sandy shores: how much room for future conservation actions is there? Ecol. Evol. 8, 10976-10988.

McGowan, C.P., Simons, T.R., 2006. Effects of human recreation on the incubation behavior of American oystercatchers. Wilson J. Ornithol. 118, 485-493.

McGowan, C.P., Simons, T.R., Golder, W., Cordes, J., 2005a. A comparison of American oystercatcher reproductive success on barrier beach and river island habitats in coastal North Carolina. Waterbirds 28, 150-155.

McGowan, C.P., Schulte, S.A., Simons, T.R., 2005b. Resightings of marked American oystercatchers banded as chicks. Wilson Bull. 117, 382-385.

Merritt Jr., L., Shafer, S.C., 2012. The use preservation paradox: an examination of negotiated rulemaking at Cape Hatteras National seashore. J. Park. Recreat. Adm. $30,66-82$.

Mitchell, P.I., Scott, I., Evans, P.R., 2000. Vulnerability to severe weather and regulation of body mass of Icelandic and British redshank Tringa totanus. J. Avian Biol. 31, 511-521.
Møller, A.P., 2002. North Atlantic Oscillation (NAO) effects of climate on the relative importance of first and second clutches in a migratory passerine bird. J. Anim. Ecol. 71, 201-210.

Mustin, K., Sutherland, W., Gill, J., 2007. The complexity of predicting climate-induced ecological impacts. Clim. Res. 35, 165-175.

National Park Service, 1991. Cape Lookout National Seashore Public Use Reporting and Counting Instructions, p. 3.

National Park Service, 1993. Cape Hatteras National Seashore Public Use Reporting and Counting Instructions, p. 5.

National Park Service, 2009. American Oystercatcher (Haematopus palliatus) Research and Monitoring in North Carolina. 2009 Annual Report Prepared by Theodore R. Simons and Shiloh Schulte, p. 80.

National Park Service, 2017. https://irma.nps.gov/Stats/.

Newton, I., 2004. Population limitation in migrants. Ibis 146, 197-226.

Newton, I., 2006. Can conditions experienced during migration limit the population levels of birds? J. Ornithol. 147, 146-166.

Newton, I., 2007. Weather-related mass-mortality events in migrants. Ibis 149, 453-467.

Nol, E., 1989. Food supply and reproductive performance of the American oystercatcher in Virginia. The Condor 91, 429-435.

Packer, C., Brink, H., Kissui, B.M., Maliti, H., Kushnir, H., Caro, T., 2011. Effects of trophy hunting on lion and leopard populations in Tanzania. Conserv. Biol. 25, $142-153$.

Paris, P., Mitasova, H., 2014. Barrier island dynamics using mass center analysis: a new way to detect and track large-scale change. ISPRS Int. J. Geo Inf. 3, 49-65.

Park, T., Casella, G., 2008. The Bayesian lasso. J. Am. Stat. Assoc. 103, 681-686.

Plard, F., Bruns, H.A., Cimiotti, D.V., Helmecke, A., Hötker, H., Jeromin, H., Roodbergen, M., Schekkerman, H., Teunissen, W., van der Jeugd, H., Schaub, M., 2019. Low productivity and unsuitable management drive the decline of central European lapwing populations. Anim. Conserv. 23, 286-296.

Plummer, M. 2003. JAGS: a program for analysis of Bayesian graphical models using Gibbs sampling. In Hornik, K., Leisch, F. \& Zeileis, A. (eds) Proceedings of the 3rd International Workshop on Distributed Statistical Computing (DSC 2003). Vienna: Technische Universitat Wien.

van de Pol, M., Vindenes, Y., Sæther, B.-E., Engen, S., Ens, B.J., Oosterbeek, K. Tinbergen, J.M., 2010. Effects of climate change and variability on population dynamics in a long-lived shorebird. Ecology 91, 1192-1204.

R Core Team. 2020. R: A Language and Environment for Statistical Computing. Vienna: R Foundation for Statistical Computing. https://www.R-project.org/. Version 4.0.2.

Robinson, S.G., Fraser, J., Catlin, D., Karpanty, S.M., Altman, J., Boettcher, R., Holcomb, K., Huber, C., Hunt, K., Wilke, A., 2019. Irruptions: evidence for breeding season habitat limitation in Piping Plover (Charadrius melodus). Avian Conserv. Ecol. $14,19$.

Robinson, S.G., Gibson, D., Riecke, T.V., Fraser, J.D., Bellman, H.A, DeRose-Wilson, A., Karpanty, S.M., Walker, K.M., Catlin, D.H., 2020. Piping Plover population increase after Hurricane Sandy mediated by immigration and reproductive output. Ornithological Applications 122, 1-20. https://doi.org/10.1093/condor/duaa041.

Sabine, J.B., Meyers, J.M., Moore, C.T., Schweitzer, S.H., 2008. Effects of human activity on behavior of breeding American oystercatchers. In: Waterbirds, vol. 31. Cumberland Island National Seashore, Georgia, USA, pp. 70-82.

Sæther, B.-E., Engen, S., Matthysen, E., 2002. Demographic characteristics and population dynamical patterns of solitary birds. Science 295, 2070-2073.

Sandvik, H., Erikstad, K.E., Sæther, B.-E., 2012. Climate affects seabird population dynamics both via reproduction and adult survival. Mar. Ecol. Prog. Ser. 454, 273-284.

Saunders, S.P., Arnold, T.W., Roche, E.A., Cuthbert, F.J., 2014. Age-specific survival and recruitment of piping plovers Charadrius melodus in the Great Lakes region. J. Avian Biol. 45, 437-449.

Saunders, S.P., Cuthbert, F.J., Zipkin, E.F., 2018. Evaluating population viability and efficacy of conservation management using integrated population models. J. Appl. Ecol. 55, 1380-1392.

Schulte, S.A., Simons, T.R., 2015. Factors affecting the reproductive success of American oystercatchers Haematopus palliatus on the Outer Banks of North Carolina. Mar. Ornithol. 43, 37-47.

Schulte, S.A., Simons, T.R., 2016. Hurricane disturbance benefits nesting American oystercatchers (Haematopus palliatus). Cowa 39, 327-338.

Schwemmer, P., Hälterlein, B., Geiter, O., Günther, K., Corman, V.M., Garthe, S., 2014. Weather-related winter mortality of Eurasian oystercatchers (Haematopus ostralegus) in the Northeastern Wadden sea. Waterbirds 37, 319-330.

Simons, T.R., and Schulte, S. 2009. American oystercatcher (Haematopus palliates) research and monitoring in North Carolina. 2009 Annual Report. U.S. Department of the Interior, Geological Survey, North Carolina Cooperative Fish and Wildlife Research Unit, Department of Biology, North Carolina State University, Raleigh.

Simons, T.R., and Stocking, J.J. 2011. American Oystercatcher Conservation Initiative in North Carolina: 2011 Report. Unpublished report, U.S. Department of the Interior, Geological Survey, North Carolina Cooperative Fish and Wildlife Research Unit, Department of Biology, North Carolina State University, Raleigh.

Stillman, R.A., Goss-Custard, J.D., West, A.D., Dit Durell, S.E.A.Le.V., McGrorty, S., Caldow, R.W.G., Norris, K.J., Johnstone, I.G., Ens, B.J., Meer, J.V.D., Triplet, P. 2001. Predicting shorebird mortality and population size under different regimes of shellfishery management. J. Appl. Ecol. 38, 857-868.

Stocking, J.J., Simons, T.R., Parsons, A.W., O'Connell Jr., A.F., 2017. Managing native predators: evidence from a partial removal of raccoons (Procyon lotor) on the outer banks of North Carolina, USA. Waterbirds 40, 10-18.

Turchin, P., 1999. Population regulation: a synthetic view. Oikos 84, 153-159.

U.S. Fish and Wildlife Service [USFWS], 1996. Piping Plover (Charadrius melodus), Atlantic Coast Population, Revised Recovery Plan (Hadley, Massachusetts, USA). 
U.S. Fish and Wildlife Service [USFWS], 2019. Abundance and Productivity Estimates 2018 Update: Atlantic Coast Piping Plover Population (Hadley, Massachusetts, USA).

Vehtari, A., Gelman, A., Gabry, J., 2017. Practical Bayesian model evaluation using leave-one-out cross-validation and WAIC. Stat. Comput. 27, 1413-1432.

Vehtari, A., Gabry, J., Yao, Y., Gelman, A., 2018. loo: efficient leave-one-out crossvalidation and WAIC for Bayesian models. R package version 2.0.0. URL: https: validation and WAIC for Bayesian mode
$/ /$ CRAN.R-project.org/package $=$ loo.

Verhulst, S., Oosterbeek, K., Ens, B.J., 2001. Experimental evidence for effects of human disturbance on foraging and parental care in oystercatchers. Biol. Conserv. 101, 375-380.

Virzi, T., 2010. The effect of human disturbance on the local distribution of American oystercatchers breeding on barrier island beaches. Wader Study Group Bull. 117, $19-26$.

Wann, G.T., Aldridge, C.L., Braun, C.E., 2014. Estimates of annual survival, growth, and recruitment of a white-tailed ptarmigan population in Colorado over 43 years. Popul. Ecol. 56, 555-567.

Weithman, C.E., Robinson, S.G., Hunt, K.L., Altman, J., Bellman, H.A., DeRose-Wilson, A. L., Walker, K.M., Fraser, J.D., Karpanty, S.M., Catlin, D.H., 2019. Growth of two Atlantic coast piping plover populations. Condor 121, 1-14.
Weithman, C.E., Fraser, J.D., Karpanty, S.M., Catlin, D.H., 2020. Relationship of current management practices to movements of piping plover broods in an Atlantic coast population. J. Field Ornithol. 91, 170-188.

West, A.D., Goss-Custard, J.D., Stillman, R.A., Caldow, R.W., dit Durell, S.E. le V. McGrorty, S., 2002. Predicting the impacts of disturbance on shorebird mortality using a behaviour-based model. Biol. Conserv. 106, 319-328.

Weston, M.A., Elgar, M.A., 2005. Disturbance to brood-rearing hooded plover Thinornis rubricollis: responses and consequences. Bird Conserv. Int. 15, 193-209.

Weston, M.A., Dodge, F., Bunce, A., Nimmo, D.G., Miller, K.K., 2012. Do temporary beach closures assist in the conservation of breeding shorebirds on recreational beaches? Pac. Conserv. Biol. 18, 47-55.

Working Group, A.O., Nol, E., Humphrey, R.C., 2012. American oystercatcher (Haematopus palliatus), version 2.0. In: Poole, A.F. (Ed.), The Birds of North America. Cornell Lab of Ornithology, Ithaca, NY, USA. https://doi.org/10.2173/bna.82.

Yalden, D.W., Pearce-Higgins, J.W., 1997. Density-dependence and winter weather as factors affecting the size of a population of golden plovers Pluvialis apricaria. Bird Study 44, 227-234.

Zuur, A.F., Ieno, E.N., Elphick, C.S., 2010. A protocol for data exploration to avoid common statistical problems. Methods Ecol. Evol. 1, 3-14. 